\title{
VERTICAL VARIABILITY \\ OF SELECTED MACROSTRUCTURAL PROPERTIES OF JUVENILE WOOD ORGANIZATION IN TRUNKS OF SCOTS PINE (PINUS SYLVESTRIS L.) TREES
}

\author{
ARKADIUSZ TOMCZAK, WITOLD PAZDROWSKI, \\ TOMASZ JELONEK, IRENEUSZ STYPUŁA \\ August Cieszkowski Agricultural University in Poznań \\ Department of Forest Utilisation \\ Wojska Polskiego 71A, 60-625 Poznań, Poland \\ e-mail: atomczak@au.poznan.pl
}

(Received: March 15, 2006. Accepted: January 16, 2007)

\begin{abstract}
The study makes an attempt to analyse the width of annual rings, the width of the latewood zone and the proportion of the latewood within juvenile wood along trunks of Scots pine (Pinus sylvestris L.) trees and to verify the hypothesis about the heterogeneous properties of juvenile wood in a single trunk. It was found that the above-mentioned macrostructural elements of wood structure showed a curvilinear correlation with the height of measurement points along the tree trunk. As the distance from the base of trunk increased, the width of the annual ring and the width of the latewood zone decreased, while the proportion of the latewood increased. These types of changes can affect positively physical and mechanical properties of wood tissue. It can be assumed that there is a mechanism which modifies properties of juvenile wood causing axial diversification of the analysed type of wood tissue. It is probable that axial heterogeneity results in advantageous changes in the mechanics of the tree trunk.
\end{abstract}

KEY WORDS: juvenile wood, axial heterogeneity, annual ring, width zone of latewood, proportion of latewood, Pinus sylvestris, maturation.

\section{INTRODUCTION}

Maturation is an integral part of plant development (Greenwood 1995). It is one of the phases organisms go through in the course of their development. Poethig (1990) maintained that shoots of higher plants pass through three, more or less, distinct post-embryonic stages: juvenile vegetative stage, mature vegetative stage and mature generative stage. However, in this sense the term 'maturation' does not refer to changes that take place in the structure and properties of wood tissue in the course of the long-term development of arborescent plants. Nevertheless, physiological changes, their consequences as well as the vertical variability of wood properties appear to run simultaneously to changes in the shoot morphology and the initiation of the generative period (Burdon et al. 2004). It is fairly difficult to prove the connection of the consecutive developmental stages of trees with wood heterogeneity because of the necessity to take into account a number of factors, especially those of external nature, which can influence the qualitative and quantitative arrangement of elements of the wood tissue structure.

The alternative warm and cold annual seasons, which occur in conditions of the temperate climate, cause that al- so in plants periods of rest and development occur with identical periodicity. The consequence of these changes is the occurrence, in arborescent plants, of annual rings made up of two distinct - with regard to structure and function zones of early and late wood. Wood heterogeneity and its symptoms, as represented by the variability of wood tissue structure within single annual increments, undergoes additional variability with regard to the width of annual rings and the proportion of latewood attributed, primarily, to the atmospheric precipitation, temperature and age. The distance of the increment from the pith can be considered as the function of age (Mäkinen 1998; Miina 2000; Wilczyński 2003, Burdon et al. 2004; Giefing et al. 2005).

Apart from the above-mentioned changes in the wood macrostructural organization, radial diversification of chemical properties and of the wood tissue anatomical structure also takes place (Fengel and Wegener 1984). On this basis, it is possible to recognize in tree trunk zones which differ from one another with a number of properties (Thörnqvist 1993; Winady 1994; Passialis and Kiriazakos 2004); so going from the pith towards the tree circumference, the following zones can be distinguished: juvenile, intermediate and mature wood zones. According to the classical approach, the homogeneous juvenile wood tissue comprises 
TABLE 1. Division of wood zones in Pinus radiata boles after Burdon et al. 2004.

\begin{tabular}{lccc}
\hline \multirow{2}{*}{ Vertical (axial) zone } & Radial zone (rings from pith, approx.) \\
\cline { 2 - 4 } & $1-5$ (inner corewood) & $6-10$ (outer corewood) & $11-15$ (transitional wood) \\
\hline Lower butt log $(<3 \mathrm{~m})$ & Juvenile corewood & Juvenile transitional wood & Juvenile outerwood \\
Vertical transition zone & Transitional corewood & Double transition zone & Mature transitional wood \\
Mid-logs & Mature corewood & Mature transitional wood & Mature outerwood \\
Toplog $(<13$ rings $)$ & Mature corewood & Almost non-existent & \\
\hline
\end{tabular}

from a few to several annual rings assuming - on the longitudinal section of the bole or trunk - the form of a solid with its base at the butt end and the peak at the top end of the trunk (Zobel and Sprague 1998).

Burdon and his co-workers (2004) maintain that the influence of the maturing apical meristem on the development of wood tissue properties is very big. That is why the authors, in the case of Pinus radiate, put forward an alternative to the conventional classification division of juvenile/mature wood zones as presented in Table 1.

Disregarding the radial division into wood zones proposed in Table 1, it should be stressed that the authors distinguish three distinct zones of pith wood - juvenile, intermediate and mature. Therefore, they imply that the wood described - according to the classical concept - as juvenile wood is characterised by vertical heterogeneity.

Juvenile wood is the type of wood tissue which occurs in each tree. In comparison with the mature wood, the juvenile type of tissue is characterised by lower strength parameters (Pazdrowski 2004). Its proportion, across the trunk cross section increases in the direction from the butt end towards the top where it can even achieve $100 \%$. Bearing in mind the increasing proportion of the juvenile wood tissue and its physico-mechanical properties, it can be assumed that the average wood strength decreases along the trunk in the direction from the top of the bole. Trunk deflections caused, among others, by the wind lead to the occurrence of compression and tensile forces as well as trunk torsion. An exceptionally strong moment of force can damage or even break the trunk (Peltola et al. 1999). Therefore, a question arises whether the increase proportion of juvenile wood across the trunk cross section can result in the decline of its strength. Therefore, the vertical variability of the wood juvenile tissue determined in Table 1 appears to be a logical outcome of the tree endeavour to maintain stability and survive as an individual.

The results presented in this study are based on easily determinable elements of macrostructural wood organisation such as the width of rings and the proportion of latewood. The monitoring of these two parameters can constitute the basis for the initial conclusion concerning changes in wood mechanical and physical properties.

The aim of the performed experiments was to analyse the variability of selected macrostructural elements of the trunk juvenile wood organisation of Scots pine (Pinus sylvestris L.) trees and to verify the hypothesis about the heterogeneity of the wood tissue situated within a few to several annual rings placed closest to the tree pith and referred to as wood juvenile tissue. The obtained results will be used as a basis for the rationalisation of the utilisation of wood raw material, especially of that obtained in the course of stand thinnings in stands of younger age classes.

\section{MATERIAL AND METHODS}

The investigations were carried out in the Miastko Forest District which is administered by the Regional Directorate of State Forests in Szczecinek and is situated mainly in the Baltic Natural Forest Region.

Analyses were performed on 48 model trunks of Scots pines (Pinus sylvestris L.) developed in two kinds of forest site types typical for this forest-forming species, namely: fresh coniferous and fresh mixed coniferous forest site types. The total of 16 surfaces were selected on the abovementioned forest site types applying the criterion of stand quality and age. The stands were divided into 4 age groups corresponding to four age classes, namely II, III, IV and V.

The size of experimental plots of the shape of a 50 by $100 \mathrm{~m}$ rectangle was $0.5 \mathrm{ha}$. The following measurements were performed on each of the selected test surfaces: breast heights of all growing trees as well as the heights of selected trees proportionally to the number of trees in the adopted $2 \mathrm{~cm}$ degrees of thickness. Next, on the basis of the obtained numerical data, dimensions of model trees were calculated applying the Urich's II dendrometric method (Grochowski 1978). Using the obtained numerical data and the tree biological classification developed by Kraft (1884), three trees were selected on each of the experimental surfaces. The selected trees comprised: one predominant, one dominant and one co-dominant tree. Following permanent marking on tree trunks of the north direction, the trees were cut in accordance with the appropriate rule and regulations. The next stage of investigations comprised the selection of the material for further analyses. This involved cutting out of wood discs from the base of the trunk (the bottom face-end which was the plane of the tree cutting) and next $1 \mathrm{~m}$ above this plane and later at the distance of 2 $\mathrm{m}$ up to the top of the bole.

After the initial preparation of discs, i.e. polishing their surfaces, widths of early and latewood zones of each annual ring were measured along four world directions with 0.1 $\mathrm{mm}$ accuracy. These measurements were carried out with the assistance of an increment metre coupled with a computer. Next, mean widths for early and latewood were calculated for each annual ring. During subsequent analyses, the following measurements were performed: the width of annual increments, proportion of latewood and the ratio of latewood width to the early wood width. The analysis of the radial dynamics of changes in the calculated ratio of latewood width to the early wood width allowed to determine fairly accurately the range of individual types of wood tissue, i.e. juvenile, intermediate and mature.

Having at the disposal the number of rings of the juvenile wood, the mean increment width, mean width of the latewood zone and mean proportion of latewood were deter- 
mined on each of the analysed cross sections and the obtained results were presented in Table and Figures. The obtained empirical material was analysed with the assistance of mathematical statistics employing, for this purpose, the Statistica 6 PL computer software (Żuk 1989; Kala 1997; Stanisz 1998).

\section{RESEARCH RESULTS}

Figures 1a-c and Table 2 presents statistical characteristics of the width of annual rings, latewood zone and the
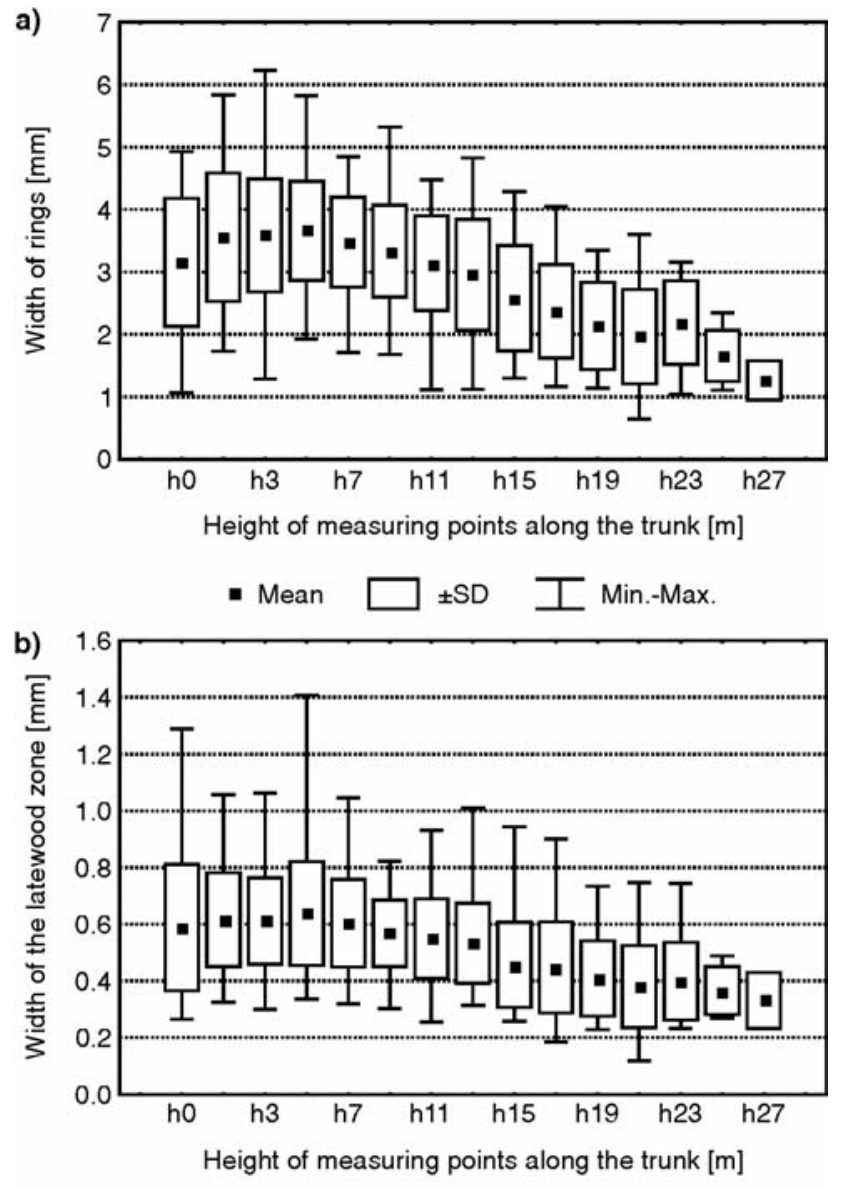

- Mean $\square \pm$ SD I Min.-Max.

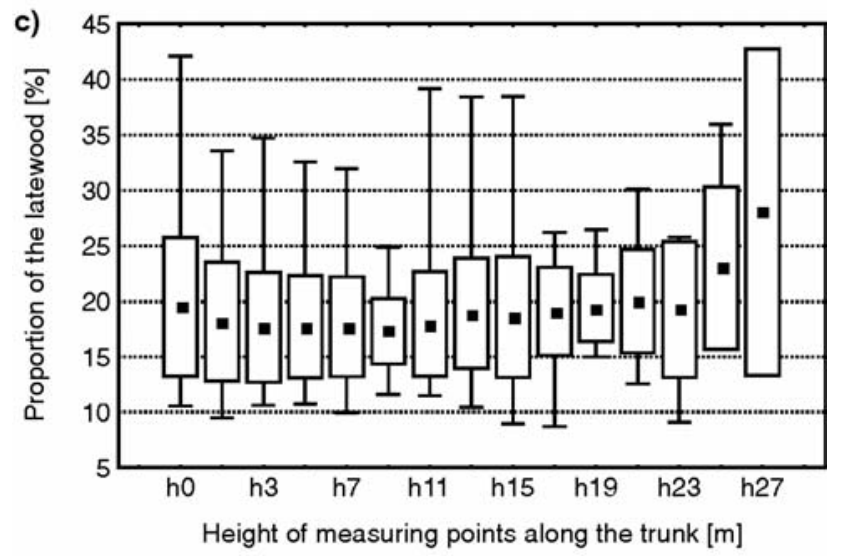

- Mean $\square \pm S D T$ Min.-Max

Fig. 1. Statistical characteristics of a) the width of annual rings, b) the width of the latewood zone and c) the proportion of latewood within juvenile wood along trunks of Scots pine trees (Pinus sylvestris L.).
TABLE 2. Variability coefficient of the width of annual rings and the width of the latewood zone within juvenile wood along trunks of Scots pine trees (Pinus sylvestris L.).

Variability coefficient [\%]

\begin{tabular}{ccc}
\hline $\begin{array}{c}\text { Position of the } \\
\text { measuring point }[\mathrm{m}]\end{array}$ & Annual rings & Width of the latewood \\
\hline 0 & 32.5 & 38.0 \\
1 & 29.0 & 26.9 \\
3 & 25.1 & 24.9 \\
5 & 21.7 & 28.8 \\
7 & 20.7 & 25.6 \\
9 & 22.1 & 20.6 \\
11 & 24.1 & 25.7 \\
13 & 30.0 & 26.5 \\
15 & 32.8 & 32.9 \\
17 & 31.8 & 36.1 \\
19 & 32.7 & 32.4 \\
21 & 38.6 & 37.9 \\
23 & 30.6 & 34.4 \\
25 & 24.8 & 23.1 \\
27 & 24.9 & 29.6 \\
\hline
\end{tabular}

proportion of latewood in the annual ring thickness within juvenile wood along the length of Scots pine trunks. The variability of the ring width and the proportion of latewood are presented graphically in Figure 2.

The lowest value of the variability coefficient of the annual ring width within the juvenile wood zone was found in the trunk cross section situated on the seventh meter from the bottom face-end. In the case of the width of the latewood zone, the lowest value of the standard deviation was determined at the height of $9 \mathrm{~m}$, while for the proportion of latewood - the minimum value of this coefficient was found at the height of $9 \mathrm{~m}$. Analysing the vertical distribution of the variability coefficient value as a set of numbers describing its internal diversification, it can be assumed that, to a certain degree, it is a measure of homogeneity of the wood tissue. Adopting this train of thought, it can be said that the juvenile wood tissue in the trunks of Scots pines is characterised by a considerable homogeneity with regard to the width of annual increments and latewood zone. In the case of the standard deviation associated with the proportion of latewood, it can be noticed that the individual values at consecutive heights do not show significant deviations with regard to one another. The only exception to this rule is this value for the height of $27 \mathrm{me}-$ ters (Figure 1c).

Analysis of variance shows, that there are observed substantial statistic differences between groups from analysed measurement levels in relation to width of yearly ring and width of latewood reach. This statistic differences was not observed in relation to latewood proportion (Table 3).

In order to answer which one from analysed groups is responsible for rejecting hypothesis stating that there is no substantial difference, Tukey's RIR test for not equal numbers was applied (Table 4, 5).

The width of annual rings within the juvenile wood zone increases up to the height of about five meters. Above this level, the value of this trait decreases but it increases between the height of 21 and 23 meters and then it declines again. The run of the curve describing changes in the percentage proportion of latewood in annual rings is almost a mirror copy of the curve which characterises annual in- 


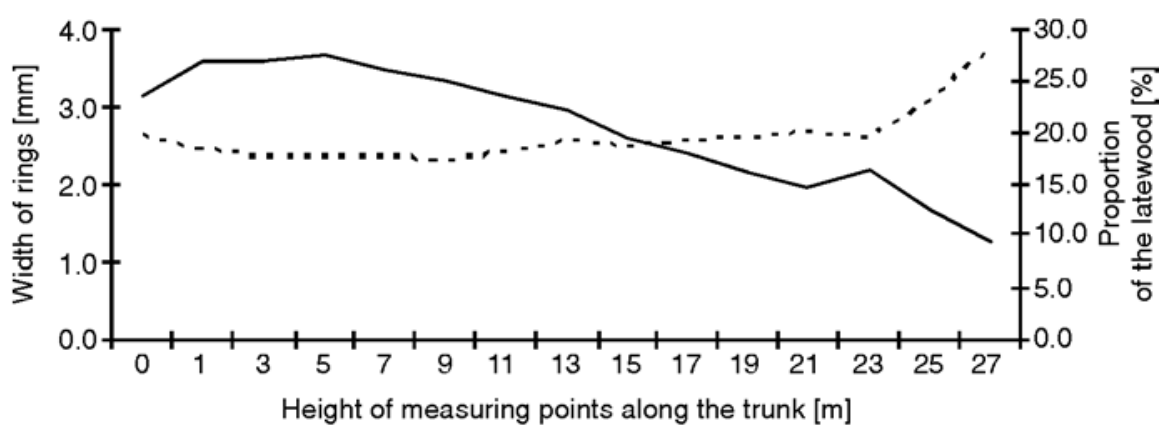

Annual rings

Proportion of the latewood
Fig. 2. Axial variability of the width of annual rings and the proportion of latewood of the juvenile wood tissue in trunks of Scots pines.

TABLE 3. Results of the analysis of variance for the width of rings, the width of the latewood zone, the proportion of the latewood between height of measurement points along the trunk.

\begin{tabular}{|c|c|c|c|c|c|c|c|c|}
\hline & $\begin{array}{l}\text { SS between } \\
\text { groups }\end{array}$ & $\begin{array}{l}\text { df between } \\
\text { groups }\end{array}$ & $\begin{array}{l}\text { MS between } \\
\text { groups }\end{array}$ & SS residual & df residual & MS residual & $\mathrm{F}$ & $\mathrm{p}$ \\
\hline Width of rings & 165.17 & 14 & 11.80 & 362.56 & 521 & 0.70 & 16.9541 & 0.0000 \\
\hline Width of the latewood zone & 3.58 & 14 & 0.26 & 13.06 & 521 & 0.03 & 10.1953 & 0.0000 \\
\hline Proportion of the latewood & 639.95 & 14 & 45.71 & 12357.25 & 521 & 23.72 & 1.9272 & 0.0216 \\
\hline
\end{tabular}

$\mathrm{SS}$ - sum of sqares; MS - mean squares; df - degrees of freedom; $\mathrm{p}$ - computer significance level

Marked effects are significant with $\mathrm{p}<0.01$

TABLE 4. The results of test RIR Tukey's shows differences between width of annual rings along the trunk in the juvenile wood zone.

\begin{tabular}{|c|c|c|c|c|c|c|c|c|c|c|c|c|c|c|c|}
\hline & 0 & 1 & 3 & 5 & 7 & 9 & 11 & 13 & 15 & 17 & 19 & 21 & 23 & 25 & 27 \\
\hline 0 & & 0.5368 & 0.4058 & 0.1580 & 0.8548 & 0.9993 & 1.0000 & 0.9984 & 0.0937 & 0.0030 & 0.0004 & 0.0001 & 0.2311 & 0.1144 & 0.6145 \\
\hline 1 & 0.5368 & & 1.0000 & 1.0000 & 1.0000 & 0.9936 & 0.4915 & 0.0393 & 0.0000 & 0.0000 & 0.0000 & 0.0000 & 0.0053 & 0.0069 & 0.2734 \\
\hline 3 & 0.4058 & 1.0000 & & 1.0000 & 1.0000 & 0.9787 & 0.3643 & 0.0218 & 0.0000 & 0.0000 & 0.0000 & 0.0000 & 0.0037 & 0.0054 & 0.2529 \\
\hline 5 & 0.1580 & 1.0000 & 1.0000 & & 0.9991 & 0.8418 & 0.1353 & 0.0043 & 0.0000 & 0.0000 & 0.0000 & 0.0000 & 0.0015 & 0.0029 & 0.2064 \\
\hline 7 & 0.8548 & 1.0000 & 1.0000 & 0.9991 & & 1.0000 & 0.8232 & 0.1520 & 0.0001 & 0.0000 & 0.0000 & 0.0000 & 0.0132 & 0.0131 & 0.3327 \\
\hline 9 & 0.9993 & 0.9936 & 0.9787 & 0.8418 & 1.0000 & & 0.9987 & 0.6741 & 0.0027 & 0.0001 & 0.0000 & 0.0000 & 0.0549 & 0.0367 & 0.4509 \\
\hline 13 & 0.9984 & 0.0393 & 0.0218 & 0.0043 & 0.1520 & 0.6741 & 0.9991 & & 0.7434 & 0.1182 & 0.0157 & 0.0036 & 0.6326 & 0.3064 & 0.7810 \\
\hline 15 & 0.0937 & 0.0000 & 0.0000 & 0.0000 & 0.0001 & 0.0027 & 0.1097 & 0.7434 & & 0.9991 & 0.8011 & 0.4169 & 0.9986 & 0.8497 & 0.9644 \\
\hline 17 & 0.0030 & 0.0000 & 0.0000 & 0.0000 & 0.0000 & 0.0001 & 0.0038 & 0.1182 & 0.9991 & & 0.9993 & 0.9395 & 1.0000 & 0.9789 & 0.9925 \\
\hline 19 & 0.0004 & 0.0000 & 0.0000 & 0.0000 & 0.0000 & 0.0000 & 0.0004 & 0.0157 & 0.8011 & 0.9993 & & 1.0000 & 1.0000 & 0.9996 & 0.9994 \\
\hline 21 & 0.0001 & 0.0000 & 0.0000 & 0.0000 & 0.0000 & 0.0000 & 0.0001 & 0.0036 & 0.4169 & 0.9395 & 1.0000 & & 1.0000 & 1.0000 & 1.0000 \\
\hline 23 & 0.2311 & 0.0053 & 0.0037 & 0.0015 & 0.0132 & 0.0549 & 0.2471 & 0.6326 & 0.9986 & 1.0000 & 1.0000 & 1.0000 & & 0.9988 & 0.9988 \\
\hline 25 & 0.1144 & 0.0069 & 0.0054 & 0.0029 & 0.0131 & 0.0367 & 0.1211 & 0.3064 & 0.8497 & 0.9789 & 0.9996 & 1.0000 & 0.9988 & & 1.0000 \\
\hline
\end{tabular}

Marked effects are significant with $\mathrm{p}<0.01$

TABLE 5. The results of test RIR Tukey's shows differences between width of the latewood zone along the trunk in the juvenile wood zone.

\begin{tabular}{|c|c|c|c|c|c|c|c|c|c|c|c|c|c|c|c|}
\hline & 0 & 1 & 3 & 5 & 7 & 9 & 11 & 13 & 15 & 17 & 19 & 21 & 23 & 25 & 27 \\
\hline 0 & & 1.000 & 1.000 & 0.976 & 1.000 & 1.000 & 0.996 & 0.941 & 0.011 & 0.007 & 0.001 & 0.001 & 0.177 & 0.482 & 0.952 \\
\hline 1 & 1.000 & & 1.000 & 1.000 & 1.000 & 0.977 & 0.749 & 0.442 & 0.000 & 0.000 & 0.000 & 0.000 & 0.055 & 0.280 & 0.897 \\
\hline 3 & 1.000 & 1.000 & & 1.000 & 1.000 & 0.991 & 0.832 & 0.543 & 0.001 & 0.000 & 0.000 & 0.000 & 0.068 & 0.310 & 0.908 \\
\hline 5 & 0.976 & 1.000 & 1.000 & & 0.999 & 0.697 & 0.280 & 0.104 & 0.000 & 0.000 & 0.000 & 0.000 & 0.018 & 0.163 & 0.834 \\
\hline 7 & 1.000 & 1.000 & 1.000 & 0.999 & & 0.999 & 0.936 & 0.723 & 0.002 & 0.001 & 0.000 & 0.000 & 0.098 & 0.367 & 0.926 \\
\hline 9 & 1.000 & 0.977 & 0.991 & 0.697 & 0.999 & & 1.000 & 0.999 & 0.084 & 0.056 & 0.011 & 0.004 & 0.360 & 0.656 & 0.977 \\
\hline 13 & 0.941 & 0.442 & 0.543 & 0.104 & 0.723 & 0.999 & 1.000 & & 0.642 & 0.514 & 0.151 & 0.056 & 0.745 & 0.883 & 0.995 \\
\hline 15 & 0.011 & 0.000 & 0.001 & 0.000 & 0.002 & 0.084 & 0.322 & 0.642 & & 1.000 & 0.998 & 0.943 & 1.000 & 1.000 & 1.000 \\
\hline 17 & 0.007 & 0.000 & 0.000 & 0.000 & 0.001 & 0.056 & 0.233 & 0.514 & 1.000 & & 1.000 & 0.980 & 1.000 & 1.000 & 1.000 \\
\hline 19 & 0.001 & 0.000 & 0.000 & 0.000 & 0.000 & 0.011 & 0.053 & 0.151 & 0.998 & 1.000 & & 1.000 & 1.000 & 1.000 & 1.000 \\
\hline 21 & 0.001 & 0.000 & 0.000 & 0.000 & 0.000 & 0.004 & 0.018 & 0.056 & 0.943 & 0.980 & 1.000 & & 1.000 & 1.000 & 1.000 \\
\hline 23 & 0.177 & 0.055 & 0.068 & 0.018 & 0.098 & 0.360 & 0.574 & 0.745 & 1.000 & 1.000 & 1.000 & 1.000 & & 1.000 & 1.000 \\
\hline 25 & 0.482 & 0.280 & 0.310 & 0.163 & 0.367 & 0.656 & 0.796 & 0.883 & 1.000 & 1.000 & 1.000 & 1.000 & 1.000 & & 1.000 \\
\hline
\end{tabular}

Marked effects are significant with $\mathrm{p}<0.01$ 
crements (Fig. 2). Despite the occurrence of variations in mean values at successive heights, it seems that the width of annual rings exhibits a negative correlation with the height of measuring points along tree trunks, whereas that of the latewood proportion - a positive correlation.

The above observations are confirmed by the runs of regression curves describing the above-mentioned relationships presented in Figures $3 \mathrm{a}$ and 3c. The curvilinear character of the trend line stresses the diverse dynamics of changes of one trait in relation to the other along tree trunks. As regards the interrelationship between the ring width and the height of the measuring point along trunks, it can be observed that the dynamics of changes in the bottom sections is negligible. However, it increases significantly from the height of about $8-10 \mathrm{~m}$ and remains high up to the top parts of the trunk. Identical situation is observed with regard to the proportion of latewood. However, here the correlation is positive and the dynamics of changes - in comparison with the ring width - is not so significant. The run of the curve describing the axial variability of the latewood zone width is similar to that of the regression curve of the ring width (Fig. 3b). Bearing in mind the above-presented interrelationships, it can be stated that the dynamics of the width changes of the latewood zone in relation to the height of the measuring point along the trunk is lower in comparison with the dynamics of changes of the ring width. The effect of this difference is, perhaps, the in-
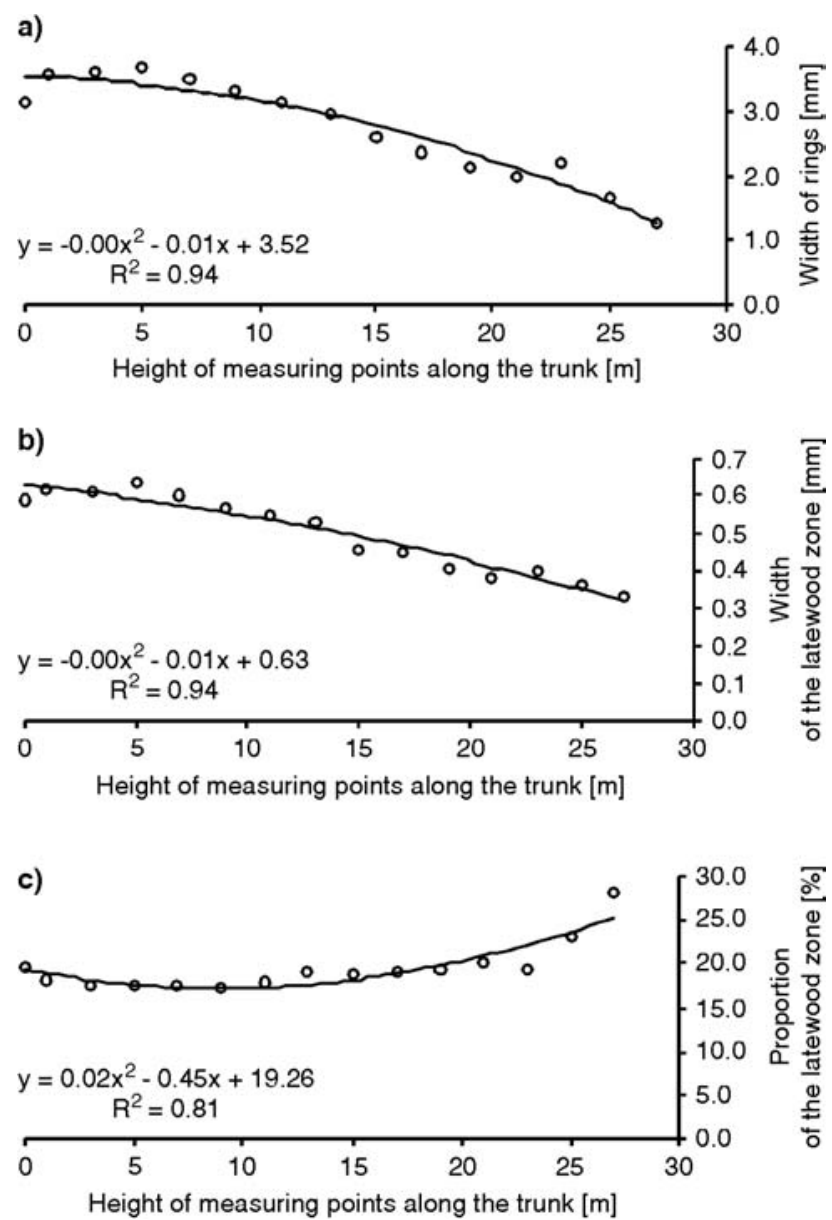

Fig. 3. Interrelationships between: a) ring width; b) width of latewood zone and c) proportion of latewood and the height of measuring point along the trunk in the juvenile wood zone of Scots pine trunks. creased proportion of latewood in the annual thickness increment.

The correlation between the width of rings, the width of the latewood zone and between the proportion of latewood in the annual increments of the juvenile wood zone and the height of the measuring points along tree trunks was also characterised with the assistance of the determination coefficient $\mathrm{R}^{2}$. Its value determines the percentage interrelationship of two characters. It is evident from Figures 3ac that the width of annual rings depends: in $94 \%$ on the height of measuring points along the tree trunk, in $94 \%$ - on the width of the latewood zone and in $81 \%$ - on the proportion of latewood.

\section{DISCUSSION}

The tree morphological variability observed in these plants is caused by the existence of developmental strains and stresses (Pascale 2002). The newly developed wood layer tends to contract but this tendency is counteracted by the existing wood. Consequently, the most outer wood layer is stretched, while the inner one - compressed (Hejnowicz 2002). The role of developmental strains for the mechanical properties of the trunk is huge, especially for withstanding such unfavourable factors as wind which can break the trunk. Trunk damage in the form of fracture may occur, on the one hand, as a result of the decline in the rate of wood deposition and weakening of developmental stresses (Hejnowicz 2002) and, on the other, as a consequence of wood defects present in trunks (Jakubowski 2005).

In the case of tree growing in open spaces, the strongest moment of force occurs at the very base of the trunk. In the case of trees growing in communities, this point will move toward the top sections of trunks with the increase of stand density. As the distance from the base of the tree trunk increases, so does the proportion of juvenile wood on the trunk cross section. Hence, the apical trunk section will be made up, primarily, from juvenile wood which will be responsible for the transfer of strains and stresses as well as the branch load together with their assimilation apparatus. Moreover, the upper parts of boles are classified as medium-size raw material intended for chemical processing, mainly into cellulose. Unfavourable properties of juvenile wood make it necessary to supplement cellulose pulp with wood which is characterised by properties of mature tissue and that increases production costs (Kretschmann 1988).

The obtained results of axial variability of the selected elements of juvenile wood macrostructural organisation show that, with the increase of tree height, the width of annual rings decreases, while the proportion of latewood increases. In the case of coniferous trees, changes of this type may exert a beneficial impact on changes of physical and mechanical properties. It can be assumed that, in the case of maturing and mature trees, a special structure of juvenile wood develops in the upper segments of trunks which differs significantly from the juvenile wood tissue derived from the lower sections of the trunk. This observation is in keeping with the hypotheses put forward by Burdon and co-workers (2004). On the other hand, it can also be assumed that this situation is connected with changes in the dynamics of wood tissue development which occur with the age of trees. The process of wood tissue aging comprises 
the entire volume of trunks or boles, including the apex section (Grzeczyński and Spława-Neyman 1980). Bearing in mind the above argument, the age factor should be treated as one that has a significant influence on the vertical variability of wood tissue macrostructural properties, especially of the juvenile and maturing tissues.

In their studies on the variability of selected properties of juvenile wood, Helińska-Raczkowska and Fabisiak (1994) reported a similar dependence between the tree height and increment width. They also presented research results concerning anatomical elements of wood structure which showed that both the diameter and thickness of tracheid cells decreased. However, the above authors stress that their results require verification on the basis of larger experimental material collected more frequently along the tree trunk. Nevertheless, the reported results refer to the character of changes occurring in the juvenile wood structure not only on the macro- but also on the microstructural level.

The change dynamics of the selected wood traits was not identical along the analysed height positions of the measurement planes. On the basis of the regression curves, it was found that in the case of bottom trunk sections (developed during a relatively young age of trees) up to the height of 8 $\mathrm{m}$, juvenile wood increments showed similar widths and this trait began to drop dynamically somewhat later. In general, trees aged 10-12 years reach the height of approximately 8-10 m. According to Kučera (1994), it is at this age that mature wood begins to appear in the bottom sections of trunks. Results obtained in our studies may suggest that the differentiation of the wood tissue in tree trunks takes place not in a small section of the trunk but rather the mechanism occurs in the entire trunk (tree) as a whole. This is also the period when the initial phase of self-thinning of trunks sets in, which means that the gravity point begins to move upwards, towards the apex. At this stage of stand development, there is very little danger from wind because trees grow densely. However, it should be remembered that the process of competitions and natural dying out is extremely intense in this period. Therefore, young trees may have at their disposal a genetically controlled adaptation mechanism which can trigger off processes modifying wood tissue characteristics and mechanical properties of the trunk. Poethig (1990) maintains that the successive changes occurring during the life cycle of a plant are controlled by a small number of genetic programs which interact with one another. The passage from one developmental phase to another is, by no means, sudden or abrupt. There are periods during plant growth and development when structures of intermediate nature develop. This is associated with the operation of more than one genetic program (Basirri, Irish, Poethig 1992).

Changes at the macro- and microstructural levels identified so far question the assumption that wood homogeneous juvenile tissue is present along the entire length of the trunk. Therefore, it is necessary to carry out further investigations at the microstructural wood level on the material derived from the top sections of trunks in order to verify the observed correlations.

\section{CONCLUSIONS}

1. The width of annual rings as well as the width of the latewood zone of wood juvenile tissue in trunks of Scots pine (Pinus sylvestris L.) decreases with the distance from the butt end, whereas the proportion of the latewood in the increment increases.

2. Narrower annual rings and higher proportion of the latewood has a positive influence on physical and mechanical properties of wood tissue. It can be presumed that there is a mechanism modifying properties of juvenile wood which results in the axial differentiation of the analysed type of wood tissue. It is probable that axial heterogeneity results in advantageous changes in the trunk (tree) mechanics subjected to strains, caused, especially, by wind.

\section{ACKNOWLEDGEMENTS}

Scientific paper financed from funds for studies in years 2005-2006 as a research project No. 2 P06L 05829 under the title: "Cyclic heterogeneity of Scots pine (Pinus sylvestris L.) against the background of the biosocial position occupied in the stand".

\section{LITERATURE CITED}

BASSIRI A., IRISH E.E., POETHIG R.S. 1992. Heterochronic effects of Teopod 2 on the growth and photosensitivity of the maize shoot. The Plant Cell. 4: 497-504.

BURDON D.R., KIBBLEWHITE R.P., WALKER J.C.F., MEGRAW R.A., EVANS R., COWN D.J. 2004. Juvenile versus mature wood: a new concept, orthogonal to corewood versus outerwood, with special reference to Pinus radiata and Pinus tadea. Forest Sci., 50 (4): 399-415.

FENGEL W., WEGENER G. 1984. Wood: Chemistry, Ultrastructure, Reactions. Walter de Gruyter, Berlin-New York.

GIEFING D.F., PAZDROWSKI W., SPŁAWA-NEYMAN S., JELONEK T., TOMCZAK A. 2005. Wood radial cyclic heterogeneity of Norway spruce (Picea abies (L.) Karst.) derived from ripening stands. EJPAU, vol. 8, issue 4, series Forestry.

GREENWOOD M.S. 1995. Juvenility and maturation in conifers: current concepts. Tree Physiol., 15: 433-438.

GROCHOWSKI J. 1978. Dendrometria. PWRiL, Warszawa. (in Polish)

GRZECZYŃSKI T, SPŁAWA-NEYMAN S. 1980. Właściwości przyobwodowej tkanki drewna sosny zwyczajnej (Pinus sylvestris L.) w zależności od wieku i bonitacji siedliska. Prace ITD., R. XXVII, 3: 3-17. (in Polish)

HEJNOWICZ Z. 2002. Anatomia i histogeneza roślin naczyniowych. PWN, Warszawa, p. 980. (in Polish)

HELIŃSKA-RACZKOWSKA L., FABISIAK E. 1994 Zmienność wybranych cech budowy drewna młodocianego drewna sosny wzdłuż wysokości drzew. Roczniki Akademii Rolniczej w Poznaniu, CCLXII: 3-13. (in Polish)

JAKUBOWSKI M., PAZDROWSKI W., SZABAN J., TOMCZAK A. 2005. The reaction wood as a one of the cause of windbreaks arising in pine trees. In: Kusta, A., Deikus, J. (eds), Human and Nature Safety 10: 89-90.

KALA R. 1997. Elementy wnioskowania parametrycznego dla przyrodników. Wydawnictwo Akademii Rolniczej im. A. Cieszkowskiego, Poznań, p. 153. (in Polish)

KRAFT G. 1884. Durchforstungen, Schlagstellungen und Lichtungshieben. Klindworth's Verlag, Hannover. (in German) 
KRETSCHMANN D.E. 1998. Properties of juvenile wood. Techline: Properties and Use of Wood, Composites, and Fiber Products, Forest Service, Issued 09/98.

KUČERA B. 1994. A hypothesis relating current annual height increment to juvenile wood formation in Norway spruce. Wood Fiber Sci., 26: 152-167.

MÄKINEN H. 1998. The suitability of height and radial increment variation in Pinus sylvestris L. for expressing environmental signals. For. Ecol. Manage., 112 (1): 191-197.

MIINA J. 2000. Dependence of tree - ring, earlywood and latewood indices of Scots pine and Norway spruce on climatic factors in estern Finland. Ecol. Model., 13 (3): 259-273.

PASCALE W. 2002. Holzkunde, Teil 3, Holzbiologie. ETH Zürich. (in German)

PASSIALIS C., KIRIAZAKOS A. 2004. Juvenile and mature wood properties of natural - grown fir trees. Holz als Roh und Werkstoff, 62: 476-478.

PAZDROWSKI W. 2004. The proportion and some selected physical and mechanical properties of juvenile, maturing and adult wood of Black pine and Scots pine. EJPAU, vol. 7, issue 1, series Forestry.
PELTOLA H., KELLOMÄKI S., VÄISÄNEN H., IKONEN V.P. 1999. A mechanistic model for assessing the risk of wind and snow damage to single trees and stands of Scots pine, Norway spruce, and birch. Can. J. Forest Res., 29: 647-661.

POETHIG R.S. 1990. Phase change and the regulation of shoot morphogenesis in plants. Science, 250: 923-930.

STANISZ A. 1998. Przystępny kurs statystyki w oparciu o program STATISTICA PL na przykładach z medycyny. StataSoft Polska Sp. z o.o. Kraków, p. 362. (in Polish)

THÖRNQVIST T. 1993. Juvenile wood in coniferous trees. Document D13, Uppsala.

WILCZYŃSKI S. 2003. Modele "klimat - przyrost radialny" sosen z Tatr, Pienin i Ojcowa. Sylwan, 12: 27-35. (in Polish)

WINANDY J.E. 1994. Wood properties. In: Encyclopedia of Agricultural Science. Charles J. (ed.). Orlando, FL: Academic Press, 4: 549-561.

ZOBEL B.J., SPRAGUE J.R. 1998. Juvenile wood in forest trees. Springer-Verlag Berlin Heidelberg New York, p. 300.

ŻUK B. 1989. Biometria stosowana. PWN, Warszawa. (in Polish) 